\title{
ЕФЕКТИВНІ ЛОГІСТИЧНІ ПРОЦЕСИ ЯК КОНКУРЕНТНА ПЕРЕВАГА НА СВІТОВОМУ РИНКУ АВТОМОБІЛІВ
}

\author{
ЭФФЕКТИВНЫЕ ЛОГИСТИЧЕСКИЕ ПРОЦЕССЫ КАК КОНКУРЕНТНОЕ \\ ПРЕИМУЩЕСТВО НА МИРОВОМ РЫНКЕ АВТОМОБИЛЕЙ
}

\section{EFFICIENT LOGISTIC PROCESSES AS COMPETITIVE ADVANTAGES ON THE GLOBAL CAR MARKET}

Логістика - одна із основних функиій автобудівних підприємств, яка піддається постійному контролю та оцінці ефективності, так як ие одна з найбільших складових затрат організації продаж автомобілів. В статті досліджені принципи розміщення виробничих потужностей автомобільних виробників в світі. Визначені основні фактори, які впливають на рімення автовиробників стосовно розміщення виробництва в тій чи іншій країні. Запропонована система ефективного розміщення дослідницьких иентрів, виробничих майданчиків та логістичних хабів по регіонам світу. Аналіз логістичних систем автовиробників показав, щуо логістична система матеріалів автовиробників повинна базуватись на системах прогнозів виробництва автомобілів, системі «вироблено на основі доставки вчасно» та «бережливому виробництві». В статті запропонована ефективна модель руху автомобілів від заводів до кінцевого споживача представлена, щуо забезпечить економію логістичних затрат автовиробників.

Ключові слова. глобальна економіка, ринок легкових автомобілів, логістика, маркетинг.

Логистика - одна из основных функиий автопроизводителей, которая поддается постоянному контролю и оценки эффективности, так как это одна из наибольших статей затрат организации продаж автомобилей. В статье исследованы приниипь размещения производственных мощностей автомобильных производителей в мире. Определень основные факторы, которые влияют на решение автопроизводителей касательно размещения производства в той или иной стране. Предложена система эффективного размещения исследовательских центров, производственных площадок $u$ логистических хабов по регионам мира. Анализ логистических систем автопроизводителей показал, что логистическая система материалов автопроизводителей должна базироваться на системах прогнозов производства автомобилей, системе «произведено на основе поставки вовремя» $и$ «бережливом производстве». В статье предложена эффективная модель движения автомобилей от заводов к конечному потребителю, что обеспечивает экономию логистических затрат производителей.

Ключевые слова. глобальная экономика, рынок легковых автомобилей, логистика, маркетинг.

Logistics - one of the main functions of car producers that are always under control and efficiency evaluation as it is one of the biggest expenses article of cars` sales. Principles of cars` 
production sites allocation have been researched at the article. The main factors that have influence at cars 'producers' decisions regarding production sites allocation at any country of the world have been determined. The system of efficient allocation of research centres, production sites and logistic hubs in the world regions has been offered at the article. The analysis of logistic systems of cars 'producers has depicted that logistics of materials has to be based on the system of cars 'production forecasts, system "produced on the delivery in time" and "lean production". The efficient model of cars' movements from production sites to end consumers that provides cutting of logistic expenses of cars` producers has been offered at the article.

Key words. Global economy, car market, logistics, marketing.

Вступ. Сучасний глобальний ринок легкових автомобілів є основою економіки світу. Автомобільний ринок дуже циклічний по своїй природі. Так, автомобільний ринок попадав в кризу продаж на протязі останніх 15 років вже декілька раз. I такі виробники, як Chrysler та SAAB не змогли пережити коливання попиту. Негативні тенденції продаж спостерігаються і зараз. Тому, автовиробники мають змінювати та удосконалювати свою систему продаж та зменшувати свої затрати. Логістичні затрати знаходяться на другому місці за величиною у автовиробників після виробничих затрат. Логістика автомобілів автомобілебудівних підприємств починається 3 рішення розміщення виробництва, транспортування до ринку збуту, зберігання і закінчується ефективним управлінням рівнями запасів готової продукції. Основні принципи логістики - це потрібний товар по якості та кількості повинен бути доставлений в правильне місце в правильний час 3 мінімальними затратами до правильного покупця. Логістика повинна бути точною, швидкою, дешевою та зберігати цінності.

Актуальність теми визначається тим, що автовиробникам необхідно змінювати систему логістики настання кризових явищ в глобальній економіці та сповільнення темпів продаж автомобілів для отримання конкурентних переваг в затратах та швидкості виконання замовлень клієнтів.

Результати досліджень маркетингової діяльності підприємств викладено в працях багатьох вітчизняних та іноземних науковців. Серед них особливе значення мають роботи А. Ф. Павленка, А. В. Войчака, М.А. Окландера, Кальченко А.Г., В. П. Пилипчука, В.Ким Чан, Р. Моборн, Андриас А.Золтнерс та інших. Так, М.А. Окландер описав та визначив ефективність логістичних процесів підприємства [8], Кальченко А.Г. вказала, що необхідно також ефективно управляти взаємовідносинами 3 постачальниками [6]. Аналіз наукових праць 3 питань логістичних процесів та конкурентоздатності підприємства дозволив виявити, що доцільним $є$ проведення дослідження, направлене на визначення принципів ефективного розміщення дослідницьких центрів, виробничих майданчиків та логістичних хабів по регіонам світу.

Постановка завдання. Кожна галузь має свої особливості, не виключення і автомобільна. Основою маркетингової та виробничої діяльності 
глобальних автомобільних корпорацій є логістична політика. Логістика - одна iз основних функцій автобудівних підприємств, яка піддається постійному контролю та оцінці ефективності, так як це одна 3 найбільших складових затрат організації продаж автомобілів. Логістичні затрати знаходяться на другому місці за величиною у автовиробників після виробничих затрат. Тому необхідно визначити основні фактори, які впливають на рішення автовиробників стосовно розміщення виробництва в тій чи іншій країні та запропонувати систему ефективного розміщення дослідницьких центрів, виробничих майданчиків та логістичних хабів по регіонам світу. Важливим також $є$ визначити ефективну модель руху автомобілів від заводів до кінцевого споживача представлена, що забезпечить економію логістичних затрат автовиробників.

Методологія. Теоретичним i методичним підгрунтям стали такі загальнонаукові методи, як системний аналіз, синтез, індукція, дедукція, абстрагування, а також спеціальні наукові методи, в тому числі: методи соціологічних досліджень та порівняння.

Матеріалами досліджень стали теоретичні праці вчених та практичні знання та досвід автора роботи на автомобільному ринку України.

Результати дослідження. Логістика - одна із основних функцій автобудівних підприємств, яка піддається постійному контролю та оцінці ефективності, так як це одна 3 найбільших складових затрат організації продаж автомобілів [9]. Логістичні затрати знаходяться на другому місці за величиною у автовиробників після виробничих затрат. Логістика автомобілів автомобілебудівних підприємств починається 3 рішення розміщення виробництва, транспортування до ринку збуту, зберігання і закінчується ефективним управлінням рівнями запасів готової продукції. Основні принципи логістики - це потрібний товар по якості та кількості повинен бути доставлений в правильне місце в правильний час 3 мінімальними затратами до правильного покупця. Логістика повинна бути точною, швидкою, дешевою та зберігати цінності.

Для осмислення ефективності логістичних процесів, необхідно дослідити принципи розміщення виробничих потужностей автомобільних виробників в світі.

Звівши всі дані та показники автомобільного ринку в світі по регіональному принципу, можна зробити деякі висновки. Так, автовиробники приймають рішення стосовно розміщення виробництва в тій чи іншій країні виходячи з наступних факторів:

1. Ринкові або маркетингові:

1.1. Рівень розвитку і об'єм ринку.

1.2. Рівень моторизації ринку.

1.3. Зростаючий чи спадаючий ринок. 
1.4. Населеність ринку.

1.5. Близькість до інших ринків для експортних можливостей.

1.6. Наявність постачальників.

1.7. Наявність інфраструктури та доріг.

2. Економічні:

2.1. Рівень податків.

2.2. Захищенність ринку для автовиробників від імпорту.

2.3. Легкість будівництва та землевідведення.

2.4. Відкритість економіки та захист інвестицій.

2.5. Вартість енергоресурсів.

2.6. Вартість праці.

2.7. ВВП на душу населення.

2.8. Позитивні економічні тенденції та зростання економіки.

2.9. Сировинна база для виробництва.

3. Політичні:

3.1. Стабільність політичної системи країни.

3.2. Демократичний режим.

3.3. Верховенство закону.

3.4. Захист інвестицій

4. Трудові

4.1. Наявність кваліфікованої робочої сили

4.2. Наявність дешевої робочої сили

4.3. Наявність центрів освіти працівників для автомобільної промисловості.

Аналіз показує, що розміщення виробництва по географічному принципу напряму зв язане з об`ємом близьких до виробничих хабів ринків або якщо вони мають перспективи зростання. Так, найбільше автомобілів виробляється в Азії - 57\% від усього світового виробництва, хоча питома вага продаж складає $51 \%$, а це означає, що залишок експортується на інші географічні ринки [1]. Виробляти в Азії автомобілі вигідніше, ніж де інше, так як вартість енергоресурсів найменша після країн NAFTA, а вартість робочої сили незначна, але вона зростає і вже більша, ніж в Південній Америці та Африці, хоча об'єм ринків там значно менший, що підтверджує факт основного показника щодо розміщення виробництва - об'єм ринку та його потенціал.

Аналізуючі географію виробництва необхідно зупинитись на всіх ринках для розуміння перспектив виробництва та продаж.

Так, в Європі розміщено $22 \%$ всіх виробничих потужностей світу та $25 \%$ всіх продаж [1]. Це традиційний виробничий майданчик. Основними перевагами виробництва тут $є$ традиційний сталий та ємкий ринок, близькість до розвиваючих ринків Східної Свропи та Туреччини. Економіка 
найрозвиненіша, а тому купівельна спроможність населення стало висока. Але об’єм виробництва 3 кожним роком падає, так як і об'єм продаж. Виробництво переноситься в Азію та Східну Свропу. Зростання населення не відбувається, моторизація фактично максимальна, тобто фактично ринок вже повністю насичений, а тому вибування автомобілів і приріст парку буде нульовий. Тобто продажі будуть постійно сталі, без зростання. В той же час купівельна спроможність населення дуже висока, а інфраструктура найкраща серед всіх географічних зон світу. Вартість енергоресурсів та робочої сили найвищі в світі. Тому тут варто розміщувати дослідницькі, дизайнерскі та навчальні центри, а також виробництво технологічно складних автомобілів та преміум брендів.

Північна Америка характеризується збільшенням продаж в останні роки, за рахунок розвитку та виходу з кризи США, виробництво відповідно також зростає. Це перш за все пояснюється економічними факторами та зростанням населення, в основному, в Мексиці. Вартість енергоресурсів найменша в світі, вартість праці менша, ніж в Європі, але зависока по відношенню до інших частин світу. Моторизація найбільша в світі, тому цей ринок буде стало ємким з перспективою невеликого зростання, в основному, за рахунок Мексики, тому найкраще будувати заводи в Мексиці, а дослідницькі, дизайнерські та навчальні центри - в США. Тут зосереджено всього $11 \%$ світового виробництва та $14 \%$ продаж не зважаючи на те, що це батьківщина автопорома [1].

На нашу думку, Південна Америка - $\epsilon$ одним із найперспективніших ринків, хоча тут зосереджено всього 5\% виробництва та 7\% продаж світу, але темпи зростання продаж дуже високі - в середньому $20 \%$ в пятирічку та й вартість робочої сили і енергоресурсів невисока. При цьому економіка розвивається високими темпами - 30\% в п`ятирічку, а дороги будуються активно. Моторизація населення менша в 3,5 рази, ніж в Північній Америці [1]. Продажі тут будут зростати і саме тут треба розміщувати виробництво автомобільним концернам, найкраще в Бразилії чи Аргентині, де об'єм ринків найбільші.

Африка в далекій перспективі дуже позитивний ринок, він зростає найбільшими темпами, але абсолютні цифри продаж дуже малі, так як економічний розвиток регіону незначний, моторизація в 10 раз менша, ніж в Європі, але поволі ВВП зростає та й населення росте значними темпами, але інфраструктура дужу слабо розвинена. Хоча тут досить багата сировинна база, тому в Африці важливо розміщувати виробництво дешевих та устарілих моделей.

Отже, треба зробити висновок, що виробникам необхідно розміщувати центри дизайнерства, досліджень і технологій, а також навчання та штаб- 
квартири на розвинених ринках, а виробничі майданчики - на ринках, що розвиваються.

Перенос виробництва в інші регіони будуть здійснюватись на основі двох факторів: рівня затрат та рівня попиту. Рівень затрат на оплату праці все ще в декілька разів менший країнах, що розвиваються, ніж в розвинених країнах - батьківщині виробництв автомобілів. Населення країн, що розвиваються буде швидко зростати, і це буде джерелом нових покупців, в результаті чого в такі країни буде переміщуватись виробництво. I потенціал близьких ринків буде важливішим, ніж фактор затрат. Для зменшення впливу курсів локальних валют, автовиробники будуть максимально об`єднувати місце виробництва та місце продаж.

Замість країн-експортерів з високим рівнем затрат, таких як Франція, Німеччина та США, центрами виробництва для автовиробників стануть низькозатратні регіони в рамках кожного географічного регіону. Наприклад, компанія KIA має виробничі потужності в Словакії (Східна Свропа) для поставок автомобілів в Західну та Східну Європу, a Volkswagen - в Мексиці для поставок до США та Канади.

Дуже важливим 3 точки зору логістики $\epsilon$ розміщення хабів по виробництву автомобілів та запчастин. Схематично пропозиції щодо розміщення хабів представлені на рис 1 . Основа - це маркетингові показники та затрати на виробництво.

Так, виробничі потужності для країн NAFTA слід розмістити в Мексиці, де вартість виробництва найменша, а 3 іншими країнами фунціонує зона вільної торгівлі, та й відстані до США та Канади незначні, а внутрішній ринок країни дуже значний - 700 тисяч автомобілів в рік [1]. Технологічнодизайнерські центри та центри з навчання (ТДЦН) слід розмістити в США так як і виробництво люксових моделей чи технологічно складних автомобілів, де кваліфікація та рівень освіти персоналу найвищий. Тут же краще традиційно розміщувати штаб-квартири автовиробників.

Виробничі потужності для країн Південної Америки слід розмістити в Бразилії або Аргентині, де вартість виробництва незначна і відстані до інших країн Латинської Америки невелика, а внутрішній ринок країн дуже значний 2,7 млн автомобілів та 600 тисяч автомобілів в рік відповідно [1]. 

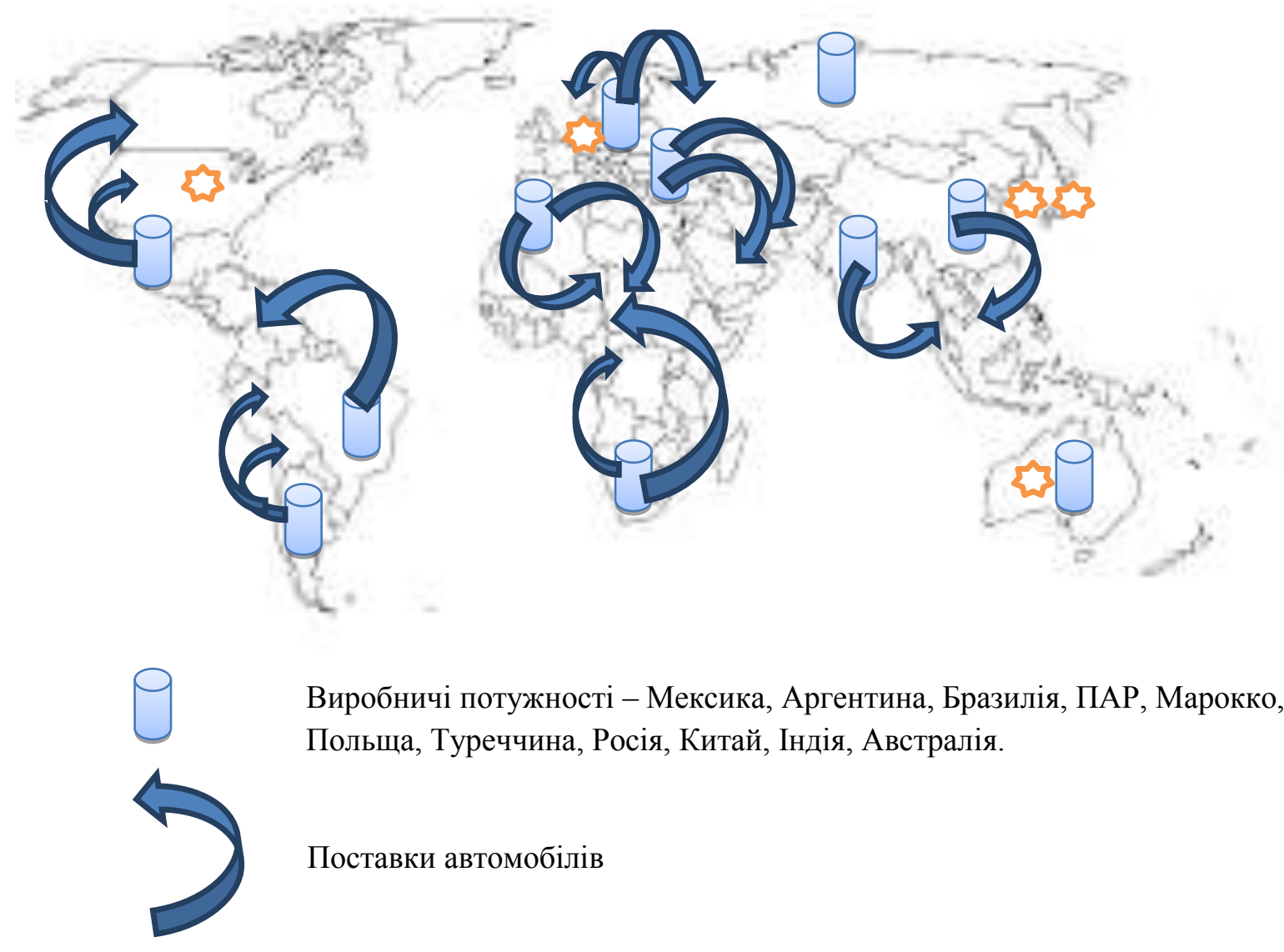

Виробничі потужності - Мексика, Аргентина, Бразилія, ПАР, Марокко, Польща, Туреччина, Росія, Китай, Індія, Австралія.

Поставки автомобілів

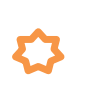

Дослідницькі, дизайнерські, технологічні та навчальні центри - США, СС, Австралія, Японія, Південна Корея

Рис 1. Проект розміщення виробничих та технологічних центрів автомобілебудівних компаній та логістичні потоки

Джерело. Складено автором.

Виробничі потужності для країн Африки слід розмістити в двох частинах материка, півночі та півдні. Так, «північ» традиційно більш розвинута частина материка, тому найбільш підходящими країнами для розміщення виробництва можуть бути країни півночі такі, як Марокко, Сгипет чи Алжир, з яких вигідно буде постачати автомобілі в глиб Африки з півночі. Ринок цих країн вимірюється в межах 200 тис авто на рік [1]. Дуже важливо тут розуміти, що ринки деяких країн закрити великими митами, тому треба досконало вивчати законодавство перед розміщенням виробництва в таких країнах, хоча ринок за десятиліття тут зріс вдвічі. Вартість виробництва незначна і відстані до інших країн Північної Африки невелика, а внутрішній ринок країн значно більший, ніж у будь-якої іншої країни регіону. Але тут треба вивчати політичні ризики, які є постійно значними. Тому, на нашу 
думку, найкращою країною щодо розміщення виробництва є Марокко, де $є$ політична стабільність та сталий економічний розвиток. На Півдні Африки найперспективніший та стабільний ринок ПАР, де ринок зростаючий та складає майже 500 тисяч автомобілів в рік, звідси можливо поставляти автомобілі в регіони південної та центральної Африки.

В Західній Свропі слід залишити тільки ТДЦН та виробництво люксових моделей чи технологічно складних автомобілів із-за надмірно дорогої робочої сили та енергоресурсів і перенести виробництво в Східну Європу, яка буде центром виробництва для всієї Європи і де робоча сила та енергоресурси коштують менше, більш лояльна податкова політика, функціонує зона вільної торгівлі, існує перспектива поставок автомобілів в Росію. Найкращим варіантом $є$ Польща, яка має перспективний ринок з точки зору об'ємів серед країн Східної Європи (300 тисяч авто в рік), та є центром Європи, а також має кваліфіковану та дешеву робочу силу.

Окремо стоять ринки Туреччини, Росії, Ірану та Австралії, які знаходяться або далеко від інших ринків і $з$ точки зору логістики краще розміщати виробництво для таких ринків в країні споживання (наприклад, Австралія), або ж захищені від імпорту, такі як Росія та Туречччина і Іран, а їх ринки є дуже значними та перспективними. Так, ринок Росії складає 2,7 млн авто, а ринок Турції - 600 тисяч, Ірану - 1 млн штук в кращі роки, крім того 3 Турції та Ірану дуже зручно буде поставляти автомобілі до Середньої Азії та Близького Сходу [1].

Азія може мати два виробничі хаби в Індії та Китаї, та ТДЦН в Японії та Кореї. Це найбільші ринки (18 млн та 2,7 млн авто відповідно) [1] та такі, що швидко розвиваються 3 малою вартістю робочої сили та енергоресурсів. Звідси можуть експортуватись автомобілі не тільки до інших країн Азії, а й до Європи та Америки в зв язку з низькою собівартістю одиниці продукції за рахунок об ємів виробництва.

Якщо ж аналізувати логістику матеріалів, необхідних для виробництва автомобілів, то автомобілебудівні компанії змушують всіх своїх постачальників розміщувати виробництво в країні виробництва автомобілів 3 ціллю локалізації виробництва та зменшення собівартості продукції та логістичних затрат.

Насьогодні, логістична система матеріалів базується на системах прогнозів виробництва автомобілів, системі «вироблено на основі доставки вчасно» та «бережливому виробництві».

Система прогнозів. Продажі базуються на прогнозах всіх автомобільних імпортерів та дилерів, автовиробники використовують прогнози як вхідні дані для виробничих програм. Виробник сам, згідно своєї статистики, розміщує у виробництво конкретні моделі та опції. Виробнича програма планується на основі консолідації всіх прогнозів та їх порівняння з усіма можливими 
потужностями виробництва для визначення того, скільки автомобілів можливо виробити на кожному заводі. Замовлення перевіряються та очікують розкладу виробництва. Потім складається графік виробництва замовлених моделей. Графік виробництва постачальників деталей - це процес, коли постачальники отримують прогнози виробництва автомобілів, актуальні графіки виробництва та щоденні зміні. Логістика деталей - це процес руху компонентів від постачальника таких деталей до заводу, який виробляє автомобілі. Потім проходить процес виробництва автомобіля. Наступний етап - це дистрибуція автомобілів згідно прогнозів та замовлень дилерів та імпортерів. Також постійно аналізується запас автомобілів на складі готової продукції, щоб він був розподілений по всім замовленням, i у випадку збільшення запасів продукціі, змінюється план замовлень та виробництва. Імпортери та дилери формують замовлення та прогнози таким чином, щоб ї запаси складали 1,5 місячні продажі, а автовиробник вимушений тримати страхові запаси готової продукції. Підсумовуючі, кількість автомобілів, які виробляються та відправляються дилерам розраховується на основі якісного методу прогнозів продаж автомобілів. Якщо прогнози дуже різняться 3 фактичними продажами, то буде перенасичення складу автомобілів у дилерів і виробники змушені будуть фінансувати кампанії по розпродажу залишків.

Система «вироблено на основі доставки вчасно». Прогноз продаж починається з того, що імпортер опитує дилерів про планові річні поставки за декілька місяців до закінчення календарного року. Потім імпортер розділяє прогнози на місячні об єми та обговорює ці плани поставок 3 дилерами, базуючись на минулорічних фактичних продажах. Прогноз попиту є основою для виробничих програм. Але при цьому методі, дилери відповідають за свої прогнози в рамках 90 днів і можуть їх змінювати тільки на четвертий місяць поставок автомобілів. Вони також зобов'язані вказувати чітко модель та конкретний двигун, а набір опцій та кольорів можливо уточнювати за 30 днів до поставки автомобіля. Виробнича програма узгоджує побажання ринків та потужності виробництва. Дуже часто потужності виробництва не можуть задовольнити попит дилерів, i тоді дефіцитні моделі направляються на найприбутковіші або важливіші ринки. Виробнича програма в реальному часі розміщує необхідні замовлення у виробників запчастин та компонентів на замовлені автомобілі, складські запаси запчастин та компонентів відсутні. Постачальник планує поставки компонентів якраз на час запланованого виробництва, максимум за неділю до початку виробництва, а іноді і раніше. Перед тим, виробник направляє прогноз поставок за 12 місяців до старту виробництва постачальнику. А після корегування плану виробництва - за 6-10 тижнів до початку виробництва. I насамкінець останні корегування - за 2-10 днів до поставки. Насправді, річні прогнози автовиробників дуже відрізняються від актуальних поставок i тому постачальники вимушені 
тримати буферні запаси для поставок автовиробникам. Така логістика може коштувати до 10\% собівартості автомобіля. Сучасне виробництво автомобілів змушує постачальників поставляти запчастини та компоненти меншими партіями та частіше, що збільшує затрати постачальників.

В процесі таких логістичних процесів виникають ряд проблем:

- неточність прогнозів продаж, який розділяє виробника та кінцевого споживача;

- неточність прогнозів продаж може призвести до надмірних запасів автомобілів у дилерів та відповідно зростання затрат;

- стрибкоподібні та неточні графіки поставок від виробника автомобілів до постачальників запасних частин та компонентів;

- затримки в вводі даних по заказам. Середня затримка в обробці замовлень - 3,8 днів;

- затримка в розробці графіків виробництва - середня протяжність обробки графіків - 30,4 дня;

- затримка в дистрибуції всередині країни - близько 10 днів;

- велика вартість вхідної та вихідної логістики.

Всі ці проблеми зменшують оборотність запасів та капіталу, а тому збільшують затрати автовиробників та авто дилерів, в структурі затрат, яких логістика складає до $30 \%$ всіх затрат.

«Lean production» або «бережливе виробництво». Таку систему логістики та виробничого процесу вперше використала компанія ТОҮОТА. Вона складається 3 трьох блоків, які створюють постійний процес руху та завантаження на максимальну потужність всіх виробничих потужностей та бізнес-процесів. Перший блок створює постійний процес виявлення проблем. Більшість бізнес-процесів - це 90\% сміття та втрати часу і тільки $10 \%$ робота, що приносить додаткову вартість. Скорочення часу від проходження сировини до створення готової продукції веде до кращої якості, зменшення затрат та скорочення часу поставок. Основна ціль «бережливого виробництва» - це створення єдиного замкнутого процесу логістики. Другий блок - це система «Тягнення» (pull). ТОҮОТА запозичила цю систему в продуктових супермаркетів. Як тільки продукт проданий 3 полиці, замовлення направляється постачальнику. Система передбачає відсутність запасів. Однак, час від часу, коли сировина перетворюється в готовий автомобіль, виникають природні затримки часу, тому деякі запаси необхідні. Третій блок вирівнює завантаження виробництва. Якщо компоненти поставлені в замовленій кількості і тільки в потрібний час, то можлива така ситуація, що надійде величезна кількість компонентів за один тиждень і виробництво та робоча сила будуть перевантажені, або ж можлива і інша протилежна ситуація, коли виробництво буде простоювати. «Бережливе виробництво» отримує загальну кількість замовлень рівномірно за період і це вирівнює завантаження 
виробництва та людей. Тому постійно виробляється такий мікс продуктів кожен день, який забезпечує безперервне виробництво. Виробник $з$ дилерами вирівнює план продаж і план виробництва для рівномірного завантаження виробництва.

Класична ж модель руху автомобілів від заводів до кінцевого споживача представлена на рис.2. Так, виробництво конкретних моделей функціонує на різних виробничих майданчиках, потім замовлення консолідується на регіональних складах автовиробника. Після цього автомобілі направляються на регіональні склади імпортерів в середині країні і тільки потім вони направляються дилерам.

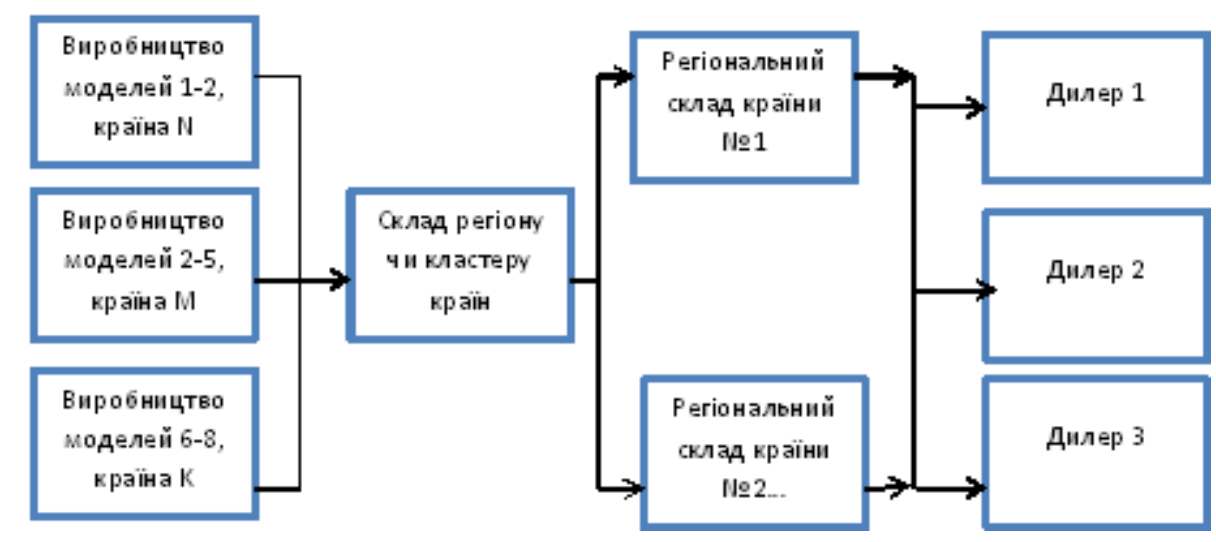

Рис. 2. Класична модель логістики автомобілів автомобільних корпорацій Джерело: складено автором

На нашу думку якщо організувати пряму поставку автомобілів з завода, та закрити ланцюг регіональних складів автовиробників та імпортерів, до дилера, то автовиробник може зекономити 100 евро на кожний автомобіль необхідних для утримання регіональних складів, а це приблизно 200 евро 3 кожного автомобіля.

Висновки. Логістичні затрати знаходяться на другому місці за величиною у автовиробників після виробничих затрат. Логістика автомобілів автомобілебудівних підприємств починається 3 рішення розміщення виробництва, транспортування до ринку збуту, зберігання і закінчується ефективним управлінням рівнями запасів готової продукції. Основні принципи логістики - це потрібний товар по якості та кількості повинен бути доставлений в правильне місце в правильний час 3 мінімальними затратами до правильного покупця. Логістика повинна бути точною, швидкою, дешевою та зберігати цінності.

У результаті проведених досліджень: 
- виявлено, що розміщення виробництва по географічному принципу напряму зв язане з об`ємом близьких до виробничих хабів ринків або якщо вони мають перспективи зростання;

- ррекомендується виробникам розміщувати центри дизайнерства, досліджень і технологій, а також навчання та штаб-квартири на розвинених ринках, а виробничі майданчики - на ринках, що розвиваються;

- пперенесення виробництва в інші регіони необхідно здійснювати на основі двох факторів: рівня затрат та рівня попиту;

- досліджено, що автомобілебудівні компанії змушують всіх своїх постачальників розміщувати виробництво в країні виробництва автомобілів з ціллю локалізації виробництва та зменшення собівартості продукції та логістичних затрат;

- необхідно організувати пряму поставку автомобілів з завода, та закрити ланцюг регіональних складів автовиробників та імпортерів, до дилера, то автовиробник може зекономити 100 евро на кожний автомобіль необхідних для утримання регіональних складів, а це приблизно 200 евро з кожного автомобіля;

Перспективи подальших досліджень полягають у розробленні методично-обгрунтованих підходів щодо логістичних процесів окремо на кожному ринку конкретної країни.

\section{Література:}

1. Матеріал з сайту. Режим доступу: www.focus2move.com

2. Пилипчук В. П. Управління продажем: Навч. посібник / В. П. Пилипчук,О. В. Данніков. - К.: КНЕУ, 2011. $-627 \mathrm{c.}$

3. В.Ким Чан, Р. Моборн. Стратегия голубого океана/ В.Ким Чан, Р. Моборн. Пер. с англ. - М.:Манн, Иванов и Фербер, 2013 - 304 с.

4. Андриас А.Золтнерс. Стратегия продаж: организация продуктовой работы торгового персонала/ Андриас А.Золтнерс, Прабхаканат Синха, Салли Э. Лоример - Пер. с англ. - Днепропетровск: Баланс Бизнес Букс, 2005. - 512 c.

5. Д. Магретта. Ключевые идеи Майкла Портера: руководство по разработке стратегии/ Д. Магретта. Пер. с англ. - М.:Манн, Иванов и Фербер, 2013 - 272 с

6. Иванов В.В., Богаченко П.В. Автомобильный менеджмент/ Иванов В.В., Богаченко П.В. - М.: ИНФРА-М, 2007. $-430 \mathrm{c}$

7. Кальченко А.Г. Логістика: Підручник/ Кальченко А.Г. — К.: КНЕУ, 2003. — 284 с

8. М.Портер. Международная конкуренция/ М.Портер. Пер. с англ. - М.:Междунар. Отношения, 1993.- 896 с.

9. Окландер М.А. Логістика: Підручник/ Окландер М.А. -К.: Центр Учбової Літератури, 2008. -346 c. 